\title{
UPAYA BIMBINGAN BACA KITAB KUNING "SYARAH AL-JURUMIYAH" PADA REMAJA MASJID BAITUSSALAM DUSUN MURBAYA KEC. PRINGGARATA LOMBOKTENGAH
}

\author{
Mustapa Ali ${ }^{1}$, Mappanyompa ${ }^{2}$, Aqodiah $^{3}$ \\ 1,3Program Studi PGMI, ${ }^{2}$ Program Studi KPI, Universitas Muhammadiyah Mataram, Indonesia \\ alimustapa1985@gmail.com ${ }^{1}$, myompakaltim@gmai.com ${ }^{2}$, aqodiiah@gmail.com ${ }^{3}$
}

\section{INFO ARTIKEL}

\section{Riwayat Artikel:}

Diterima: 03-08-2019

Disetujui: 30-10-2019

\section{Kata Kunci:}

Bimbingan Baca Kitab; Bimbingan Kitab Kuning; Syarah Al-Jurumiyah; Remaja Masjid Baitussalam.

\section{Keywords:}

Scripture reading guidance; Guidance of the Yellow Book; Sharh Al-Jurumiyah; Youth Mosque Baitussalam.

\section{A. ANALISIS SITUASI}

Remaja Masjid Baitussalam dusun Murbaya adalah kumpulan dari remaja dan remaji yang ada di desa Murbaya, dusun Murbaya, kecamatan pringgarata kabupaten Lombok Tengah. Propinsi Nusa Tenggara Barat. Dilihat dari kondisi sosial masyarakat yang tergolong masih dalam taraf kehidupan menengah ke bawah, karenanya

\section{ABSTRAK}

Abstrak: Program bimbingan kepada para generasi muda dalam hal pemahaman keagamaan akan dalil-dalil sebagai sumber pengambilan hukum Islam serta didukung oleh pemahaman dasar tentang kaidah tata bahasa Arab (ilmu nahwu) sangat diperlukan, melihat banyaknya masyarakat yang mudah percaya dengan ajaran atau aliran baru yang menyimpang dari alQur'an dan Hadit Nabi yang sohih. Berbekal pengajar dari tim dosen yang dibantu oleh mahasiswa yang komputen serta penggunaan metode studi kasus yang disesuaikan dengan kondisi masyarakat, dari segi media pembelajaran, alat-alat belajar dan metode pengajaran yang sifatnya klasik (hanya dengan mendengar, mendabit dan menghafal kaidah), maka kami akan menggunakan metode tarjamah dan mendabit makna teks kitab dan membaca intensif serta metode eklektik (campuran) dan memberikan tambahan materi penjelas berupa praktik cepat memahami kaidah bahasa Arab sesuai dengan tuntunan yang ada di dalam kitab. Adapun hasil dari pengabdian ini adalah para remaja masjid Baitussalam Murbaya yang mengikuti bimbingan mendapatkan banyak pengetahuan mengenai metode pembelajaran, peserta didik bisa membaca kitab syarah Al-Jurumiyah dan mengetahui tata cara memahami dasar pengambilan hukum serta dalil yang benar sesuai dengan al-Qur'an dan Hadits Sohih. Motivasi Remaja Masjid terlihat meningkat karena ada perbaikan dan tambahan sarana dan prasarana TPQ Al-Mustofa Murbaya. Para remaja memiliki kesadaran akan pentingnya menambah wawasan keilmuan untuk memperkuat iman dan Islam yang akan berefek positif pada ketinggian akhlaq dan akan menciptakan generasi yang berjiwa besar dalam menghadapi tantangan zaman.

\begin{abstract}
The mentoring Program to the young generation in terms of religious understanding of the evidence as a source of the retrieval of Islamic law and supported by a basic understanding of the rules of the Arabic grammar (science Nahwu) is indispensable, see the number of people That is easy to believe with the new teachings or traditions deviating from the Qur'an and the Sohih prophet Hadit. Armed with a teacher from a team of lecturers assisted by a computated student and the use of case study methods tailored to community conditions, in terms of learning media, learning tools and teaching methods that are classical in nature (only with To hear, to do and to memorize the rules), then we will use the method of Manshawi and mendabit the meaning of book text and intensive reading and an eclectic method (mix) and provide additional explanatory material in the form of quick practice understanding the rules of Arabic According to the guidance that is in the book. The result of this devotion is the youth of Baitussalam Murbaya mosque who follow the guidance of gaining a lot of knowledge about learning methods, learners can read the book Al-Jurumiyah and know the procedure to understand the basic The law and the correct evidence according to the Qur'an and Hadith Sohih. The motivation of youth mosques is seen to increase due to improvements and additional facilities and infrastructures of the TPQ Al-Mustofa Murbaya. Youth have an awareness of the importance of adding scholarly insight to strengthening faith and Islam that will have a positive effect on the heights of Akhlaq and will create a generation of great souls in the face of the challenges of the Times.
\end{abstract}

sebagian besar orang tua mereka menjadi buruh tani dan buruh bangunan. Setengah dari kepala keluarga yang ada di dusun tersebut mengadu nasip ke Malaisia dan trasimigrasi ke Kalimantan dan Sulawesi, sehingga kebanyakan dari anak-anak yang mereka khususnya para remaja-remaji yang tinggalkan di kampung tidak mendapatkan perhatian yang maksimal dari orang tua, dalam hal 
ini pendidikan yang diterima dari kedua orang tuanya sangat jauh dari harapan terutama masalah pemahaman agama, para remaja-remaji hanya mendapatkan pelajaran agama secara umum di sekolah, dan ada juga yang mengaji di rumah ustaz setempat dengan sistim pembelajaran kompensional (hanya menghafal bacaan dan tata cara shalat, dan ilmu agama pendukungnya, belajar kitab al-jurumiyah).

Sehingga prilaku dan praktek ibadah yang mereka lakukan sehari-harinya belum sempurna sesuai dengan tuntunan Nabi, terlebih lagi mereka belum mengetahui dalil atau landasan hukumnya. Proses pendidikan agama khususnya tentang memahami sumber pengambilan hukum dari kitab aslinya sehingga pengamalan ibadah akan lebih sempurna dan sesuai tuntunan Nabi Muhammad SAW belum mereka dapatkan, melainkan dari mengaji secara mendengar saja dari guru ngaji. Dan hal yang sangat disayangkan adalah para remaja-remaji selepas SMP atau SMA tidak mau lagi pergi mengaji, karena disibukkan oleh Medsos dan sejenisnya walaupun ada sebagian remaja yang melanjutkan pendidikannya ke perguruan tinggi di Mataram, akan tetapi hal tersebut tidak memberikan perubahan pada pengamalan ibadah mereka, apalagi untuk membaca sumber pengambilan hukum dari teks bahasa Arabnya terutama dari kitab hadis Nabi. Berbicara hal tersebut, masyarakat secara umum dan khususnya untuk para remaja harus mempelajari ilmu pendukung untuk memahami teks Arab (kitab hadist) agar menjadi generasi yang lebih baik dari sebelumnya.

Melalui program pegabdian masyarakat inilah kami dari tim akademisi UMmat merasa terpanggil untuk memberikan solusi pada beberapa masalah tersebut di atas, di antaranya adalah pertama; masalah jumlah remaja-remaji yang tidak memiliki guru pembimbing keagamaan dengan rasio pengajar yang kurang karena alasan para guru ngaji hanya mengajarkan anak-anak saja. Kami menawarkan bantuan sumberdaya pengajar dari tim dosen yang dibantu oleh mahasiswa yang sudah kami yakini akan kemampuannya.

Kedua; dari segi media pembelajaran, kami dari tim akan mencoba menggalang dana untuk memberikan bantuan berupa alat-alat belajar yang dibutuhkan sesuai dengan kebutuhan pembinaan mengkaji "kitab syarah al-Jurumiyah" yang akan dilaksanakan pada remaja masjid Baitussalam Murbaya Loteng.

Ketiga; dari segi metode pengajaran yang sifatnya klasik (hanya dengan mendengar, mendabit dan menghafal kaidah), maka kami akan menggunakan metode tarjamah dan mendabit makna teks kitab dan membaca intensif serta metode eklektik (campuran) dan memberikan tambahan materi penjelas berupa praktik cepat memahami kaidah bahasa Arab sesuai dengan tuntunan yang ada di dalam kitab.

Mengetahui apa yang kami tawarkan ini, dari pihak mitra sangat senang dan sangat setuju dengan apa yang akan kami lakukan nanti untuk remaja Masjid Baitussalam Murbaya, dan mitra sangat mengharapkan kehadiran tim dengan segera, karena persoalan penanaman tentang ilmu ibadah syariat yang tepat dan nilai-nilai keagamaan adalah satu kebutuhan yang sangat mendasar dan harus diutamakan yaitu dengan memahami kaidah bahasa Arab secara baik sebagai pendukungnya.

Adapun tingkat pendidikan dan jumlah remaja-remaji yang dimaksud sebagai obyek pembinaan pengabdian adalah sejumlah 22 orang dengan tingkat pendidikan yang berbeda mulai dari tingkat Mts sederajat sampai tingkat MA/SMA/SMK, dan ada sebagian yang sudah pada jenjang perguruan tinggi. Perbedaan tingkat pendidikan disiasati dengan beberapa metode pembelajaran, di antaranya adalah dengan membagi peserta didik sesuai tingkat kemahirannya, dan yang masih dalam tingkat permulaan dapat disiasati dengan tutorial sebaya. Dengan demikian proses pengenalan terkait dengan kaidah bahasa Arab (nahwu) dapat berjalam sesuai rencana.

Lebih jelasnya data remaja Masjid Baitussalam Murbaya Lombok Tengah yang mengikuti pembinaan adalah sebagai berikut:

Table.1

Remaja Masjid Baitussalam yang Mengikuti Pembinaan

\begin{tabular}{|l|l|l|l|l|l|l|}
\hline \multirow{2}{*}{ No } & \multirow{2}{*}{ Nama } & \multirow{2}{*}{$L$} & \multirow{2}{*}{$P$} & \multicolumn{3}{|l|}{ Pendidikan } \\
\hline & & & & Mts/SMP & MA/SMA & $P T$ \\
\hline 1 & M. Hamdani & $\checkmark$ & & & & $\checkmark$ \\
\hline 2 & Azim Azzarqani & $\checkmark$ & & & & $\checkmark$ \\
\hline 3 & Aditia & $\checkmark$ & & & $\checkmark$ & $\checkmark$ \\
\hline 4 & Hanani & $\checkmark$ & & & & \\
\hline 5 & Rido Haqqul H. & $\checkmark$ & & & & $\checkmark$ \\
\hline 6 & Kairul Anam & $\checkmark$ & & & $\checkmark$ & \\
\hline 7 & M. Stefen & $\checkmark$ & & & $\checkmark$ & \\
\hline 8 & Firman Syah & $\checkmark$ & & & & \\
\hline 9 & Yusfi Azila & $\checkmark$ & & $\checkmark$ & & \\
\hline 10 & M.Restu & $\checkmark$ & & $\checkmark$ & & \\
\hline 11 & Julia & & $\checkmark$ & & & \\
\hline 12 & Malasari & & $\checkmark$ & & & \\
\hline 13 & Ni'ami & & $\checkmark$ & & & \\
\hline 14 & Mar'atussolihah & & $\checkmark$ & & & \\
\hline 15 & Uswatun & & $\checkmark$ & & & \\
\hline 16 & Zahrotul 'Ain & & $\checkmark$ & & & \\
\hline 17 & Siti Fatimah & & $\checkmark$ & & & \\
\hline 18 & Linda & & $\checkmark$ & & & \\
\hline
\end{tabular}




\begin{tabular}{|l|l|l|l|l|l|l|}
\hline 19 & Fahmi Qur'an & $\checkmark$ & & & & \\
\hline 20 & Irma Fatimah & & $\checkmark$ & & $\checkmark$ & \\
\hline 21 & Iswadi & $\checkmark$ & & & $\checkmark$ & \\
\hline 22 & Mujiburrahman & $\checkmark$ & & & $\checkmark$ & \\
\hline
\end{tabular}

\section{B. PERMASALAHAN MITRA}

Permaslahan Mitra dapat dikelompokkan menjadi empat, yaitan permasalahan kegiatan keagamaan dimasyarakat, permasalahan kegiatan pendidikan keagamaan, masalah guru, dan sarana pendidikan agama. deskribsi beberapa masalah tersebut sebagai berikut:

a. Remaja Masjid Baitussalam Murbaya memang memiliki kegiatan mingguan yaitu hanya kegiatan yasinan dan memenuhi undangan tahlilan jika ada warga yang punya hajatan. Dan selebihnya adalah kegiatan bersih-bersih kampung setiap hari ahad.

b. Adapun untuk menambah wawasan keagamaan ada beberapa remaja yang mengikuti pengajian di TPQ Al-Mustofa yang berada di dusun setempat, waktunya setelah solat isyak.

c. Guru Pembina hanya satu orang ustaz dan dua orang tokoh agama lainnya yang kadangkadang masuk memembimbing para murid dan terkadang tidak bisa masuk, karena alasan mencari nafkah sehari-hari dan kesibukan yang lainnya, sehingga proses pembelajaran dan pendalaman wawasan agama berjalan tidak maksimal.

d. Dan pada kesempatan ini, pengabdian akan diadakan di TPQ Al-Mustofa. Pembinaan tidak dilaksanakan di masjid Baitussalam Murbaya, karena masjid sedang direhab. Adapun yang terkait dengan permasalahan sarana prasarana adalah:

\section{Table 2:}

Kondisi sarana dan prasarana di TPQ Al-Mustofa.

\begin{tabular}{|l|l|c|l|l|}
\hline No & Sarana dan prasarana & Jumlah & kondisi & Ket: \\
\hline 1 & Luas tanah & 3 are & & \\
\hline 2 & Ruang TPQ/musolla & $7: 9 \mathrm{~m} 2$ & Cukup baik & \\
\hline 3 & Perpustakaan & 1 & Kurang baik & \\
\hline 4 & Tempat berwudu' & 3 & Cukup baik & \\
\hline 5 & MCK bersama & 2 & Kurang baik & \\
\hline 6 & Papan Tulis & 1 & Kurang baik & \\
\hline 8 & Al-Qur'an & 40 & Kurang baik & \\
\hline 10 & Al-Qur'an terjemahan & 6 & Kurang baik & \\
\hline 11 & Syarah al-Jurumiyah & 22 & Baik & \\
\hline
\end{tabular}

\section{SOLUSI YANG DITAWARKAN}

Adapun solusi yang ditawarkan dari Tim Pengabdian untuk memecahkan masalah Melalui program pegabdian masyarakat adalah pertama; masalah kegiatan remaja untuk masyarakat ditambah dengan kegiatan mingguan mengkaji dan berdiskusi masalah agama yang terkait dengan tata cara memahami konsep ibadah sesuai dengan tuntunan hadis sohih dengan memahami kaidah dasar membaca kitab kuning (syarah AlJurumiyah). Kedua; Adapun untuk penambahan wawasan tentang praktek pengenalan kaidah bahasa Arab bagi para remaja masjid diberikan pembelajaran dengan teori dan praktek yang langsung dengan mempelajari kitab syarah alJurumiyah, yang dilakukan dengan pengenalan konsep tata bahasa Arab (nahwu). Dengan beberapa langkah diantaranya adalah:

1) Guru (tim pengabdian) membacakan isi kitab dan peserta mendabit dengan memberikan harokat pada kitab masing-masing.

2) Penyampaian materi dengan metode kawaid watarjamah (yaitu dengan mengajarkan konsep kaidah dari proses menterjemahkan materi dalam kitab tersebut. Dengan demikian peserta terbiasa membaca dan menterjemah teks Arab dan didukung dengan memahami tata bahasanya.

3) Untuk menguji tingkat keberhasilan metode ini, guru (tim Pengabdi) menguji langsung para peserta di setiap akhir pelajaran dengan membaca materi yang telah dibahas dan langsung diberikan perbaikan oleh guru.

4) Bagi para remaja pemula ditugaskan untuk belajar kembali pada teman yang sudah dianggap bisa dan memahami tata bahasa Arab dengan baik.

Dan permasalahan ketiga jumlah remajaremaji yang tidak memiliki guru pemebimbing keagamaan dengan rasio pengajar yang kurang karena alasan para guru ngaji hanya mengajarkan anak-anak saja. Kami pihak LPM memberikan bantuan sumberdaya pengajar dari tim dosen yang dibantu oleh mahasiswa yang sudah kami yakini akan kemampuannya dari segi metode pengajaran yang sifatnya klasik (hanya dengan mendengar ceramah dan menghafal), maka kami akan menggunakan metode tarjamah dan mendabit makna teks kitab dan memberikan tambahan materi penjelas berupa praktik membaca langsung dengan terjemahannya dan penjelasan contohnya tidak hanya dari kitab yang dikaji melainkan dari ayat al-Qur'an dan kitab hadist Nabi. Serta yang ke empat dari segi media pembelajaran, kami dari tim memberikan bantuan berupa alat-alat belajar yang diperlukan sesuai dengan kebutuhan pembinaan mengkaji "kitab syarah al-Jurumiyah" di antaranya adalah alat tulis menulis, satu eksemplar kitab syarah al-Jurumiyah, papan tulis dan lainsebagainya, dengan demikian kelancaran kegiatan tersebut dilaksanakan di TPQ al-Mustofa oleh para tim dari UMMAT pada remaja masjid 
Baitussalam Murbaya Loteng sesuai dengan harapan.

\section{KELAYAKAN PERGURUAN TINGGI}

Bahwa tim dosen kami memiliki SDM yang sangat cukup untuk memberikan pembelajaran kepada para remaja masjid Baitussalam Murbaya tersebut karena hal yang akan kami lakukan dengan latar belakang pendidikan tim dosen dan dibantu oleh mahasiswa pililhan sangat relevan, yakni tim dosen kami adalah lulusan S2 pendidikan Agama Islam yang sangat menguasai dibidang dedaktik metodik pengajaran tentang keagamaan dan hal yang terkait di dalamnya (lebih rincinya dapat dilihat pada curriculum vitae dosen di lembar lampiran), begitu pula dengan mahasiswa yang kami libatkan, sudah kami seleksi terlebih dahulu.

Adapun dosen yang kami sertakan dalam pengabdian ini ada dua orang yaitu;

1. Mustapa Ali, M. Pd. (ketua)

2. Mappanyompa, MM., M.Pd.I (anggota)

3. Aqodiah, M.Pd.I (anggota).

Dari mahasiswa;

1. Wahyu Kurniawan, Nim; 71512A0007

2. Yuliati, Nim; 71512A0031

3. Mar'atus Solihah. Nim; 717120011

4. Hikmah Pertiwi. Nim; 716120001

Untuk mendukung efektifitas dan kemudahan dalam evaluasi kegiatan dan pengabdian pada masyarakat, kami sertakan dengan jadwal baik daftar peserta maupun absen kehadiran team, sepersti pada table berikut di bawah ini:

Tabel. 3

Absen Kehadiran Team

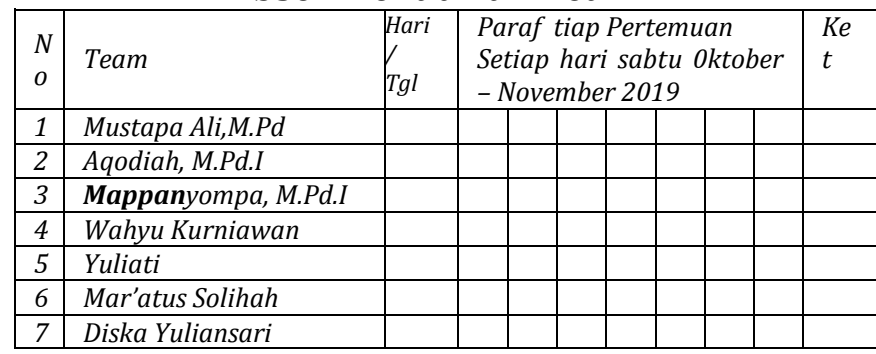

\section{E. METODE PELAKSANAAN PENGABDIAN}

\section{a. Alat dan Bahan}

Adapun alat dan bahan atau media yang digunakan dalam pembelajaran adalah

1) Papan white board

2) Spidol dan penghapus serta alat tulis untuk peserta didik

3) Kitab Syarah Al-Jurumiyah (kumpulan kaidah Nahwu/Tata bahasa Arab).

\section{b. Langkah- langkah}

Dalam pembelajaran kaifiatussolah untuk para remaja masjid baitussalam Murbaya adalah sebagai berikut:

1) Guru (Tim yang bertugas) memberikan arahan dan motivasi akan pentingnya ilmu pengetahuan Agama yang mendalam yang diperkuat dengan menguasai tata bahasa Arab yang memadai. Tidak hanya dengan membaca terjemahan atau hanya mendengar dari seorang guru ngaji.

2) Guru (Tim yang bertugas) Membacakan materi yang ada dalam kitab syarah al-jurumiyah dan para peserta didik menyimak dan mendabit artinya.

3) Guru menjelaskan makna dan tata cara penggunaan kaidah bahasa Arab yang difungsikan dalam memahami makna dalam kitab baik al-qur'an atau hadits disesuaikan keterangannya dengan kaidah yang ada dalam kitab.

4) Pada akhir pembelajaran, para peserta didik ditugaskan secara klasikal membaca kitab yang telah dipelajari, setelah itu secara individual membaca kitab syarah al-jurumiyah yang telah didabit artinya.

5) Metode yang digunakan dalam menyampaikan kaidah bahasa arab yaitu dengan tiga metode; pertama dengan metode deduktif (membacakan kaidah bahasa Arab secara umum, degan memberikan contoh dari al-Qur'an atau hadits setelah itu diberikan kesimpulan kaidah), yang kedua adalah metode induktif (yaitu dengan memberikan kaidah lalu menguraikannya dengan contoh dari al-qur'an dan hadist) dan yang ketiga adalah metode kawaid dan tarjamah (yaitu dengan menjelaskan kaidah tata bahasa Arab dengan menterjemahkanlangsung pada kitab masing-masing atau mendabitnya).

6) Pada saat demontrasi atau praktek membaca kitab syarah al-jurumiyah dilakukan oleh peserta, guru (tim yang bertugas) memberikan koreksi, pertanyaan dan cara baca yang tepat sesuai kaidah tata bahasa Arab.

Tabel. 4. Absen Peserta

\begin{tabular}{|c|c|c|c|c|c|c|c|c|}
\hline \multirow{2}{*}{ No } & \multirow{2}{*}{ Peserta } & \multicolumn{6}{|c|}{ Hari dan tanggal } & \multirow[t]{2}{*}{ ket } \\
\hline & & \begin{tabular}{|l|}
$12 / 1$ \\
$0 / 19$ \\
\end{tabular} & \begin{tabular}{|l|l|}
$12 / 1$ & $19 / 1$ \\
$0 / 19$ & $0 / 19$ \\
\end{tabular} & $\begin{array}{l}26 / 1 \\
0 / 19\end{array}$ & $\begin{array}{l}/ 11 \\
19\end{array}$ & \begin{tabular}{|l|}
$16 / 1$ \\
$1 / 19$ \\
\end{tabular} & \begin{tabular}{|l|}
$23 / 1$ \\
$1 / 19$ \\
\end{tabular} & \\
\hline 1 & M. Hamdani & & & & & & & \\
\hline 2 & Azim Azzarqani & & & & & & & \\
\hline 3 & Aditia & & & & & & & \\
\hline 4 & Hanani & & & & & & & \\
\hline 5 & Rido Haqqul Hakiki & & & & & & & \\
\hline 6 & Kairul Anam & & & & & & & \\
\hline 7 & M. Stefen & & & & & & & \\
\hline 8 & Firman Syah & & & & & & & \\
\hline 9 & Yusfi Azila & & & & & & & \\
\hline 10 & M.Restu & & & & & & & \\
\hline
\end{tabular}




\begin{tabular}{|l|l|l|l|l|l|l|l|l|l|}
\hline 11 & Julia & & & & & & & & \\
\hline 12 & Malasari & & & & & & & & \\
\hline 13 & Ni'ami & & & & & & & & \\
\hline 14 & Mar'atussolihah & & & & & & & & \\
\hline 15 & Uswatun & & & & & & & & \\
\hline 16 & Zahrotul Ain & & & & & & & & \\
\hline 17 & Siti Fatimah & & & & & & & & \\
\hline 18 & Linda & & & & & & & & \\
\hline 19 & Fahmi Qur'an & & & & & & & & \\
\hline 20 & Irma Fatimah & & & & & & & & \\
\hline 21 & Iswadi & & & & & & & & \\
\hline 22 & Mujiburrahman & & & & & & & & \\
\hline
\end{tabular}

\section{c. Waktu efektif Pelaksanaan Pengabdian}

Untuk lebih efektifnya pelaksaan pengabdian dan tujuan tercapai dibutuhkan adanya jadwal kegiatan yang akan dlaksanakan selama pengabdian berlangsung, untuk lebih jelasnya pada table berikut:

Table. 3 Jadwal Kegiatan evektif

\begin{tabular}{|c|c|c|c|}
\hline No & Hari/tgl & Materi & Pemateri \\
\hline 1 & $\begin{array}{l}\text { Sabtu } \\
5 / 10 / 2019\end{array}$ & $\begin{array}{l}\text { Pengenalan dengan Tim } \\
\text { Pengabdian }\end{array}$ & TIM \\
\hline 2 & $\begin{array}{l}\text { Sabtu } \\
2 / 10 / 2019\end{array}$ & $\begin{array}{l}\text { Uraian kaidah bahsa } \\
\text { Arab (nahwu) }\end{array}$ & $\begin{array}{l}\text { Mustapa Ali, } \\
\text { M.Pd }\end{array}$ \\
\hline 3 & $\begin{array}{l}\text { Sabtu } \\
19 / 10 / 2019\end{array}$ & $\begin{array}{l}\text { Pembahasan tentang } \\
\text { kaidah membaca dan } \\
\text { menterjemah }\end{array}$ & $\begin{array}{l}\text { Mustapa Ali, } \\
\text { M.Pd }\end{array}$ \\
\hline 4 & $\begin{array}{l}\text { Sabtu } \\
26 / 10 / 2019\end{array}$ & $\begin{array}{l}\text { Praktek dan Membaca } \\
\text { Kitab syarah al- } \\
\text { Jurumiyah }\end{array}$ & $\begin{array}{l}\text { Mustapa Ali, } \\
\text { M.Pd }\end{array}$ \\
\hline 5 & $\begin{array}{l}\text { Sabtu } \\
2 / 11 / 2019\end{array}$ & $\begin{array}{l}\text { Praktek Membaca dan } \\
\text { Menterjemah Kitab } \\
\text { syarah al-Jurumiyah }\end{array}$ & $\begin{array}{l}\text { Mustapa Ali, } \\
\text { M.Pd }\end{array}$ \\
\hline 6 & $\begin{array}{l}\text { Sabtu } \\
16 / 11 / 2019\end{array}$ & $\begin{array}{l}\text { Praktek memahami } \\
\text { konsep nahwu dalam al- } \\
\text { quran }\end{array}$ & $\begin{array}{ll}\text { Mustapa Ali, } \\
\text { M.Pd } \\
\text { dan Tim }\end{array}$ \\
\hline 7 & $\begin{array}{l}\text { Senin } \\
23 / 11 / 2019\end{array}$ & $\begin{array}{l}\text { Praktek memahami } \\
\text { konsep nahwu dalam } \\
\text { kitab Hadits }\end{array}$ & $\begin{array}{l}\text { Mustapa } \\
\text { dan Tim }\end{array}$ \\
\hline 8 & $24 / 11 / 2019$ & Evaluasi semua kegiatan & Tim \\
\hline
\end{tabular}

\section{d. Kontribusi Mitra dalam Pelaksanaan Pengabdian}

Dalam kegiatan pengabdian oleh tim dari UMMAT tersebut, pihak mitra (Remaja Masjid Baitussalam) termotivasi dan sangat mendukung serta berpartisifasi dalam seluruh kegiatan di TPQ al-Mustofa, sehingga kegiatan pengabdian berjalan sesusuai dengan harapan. Oleh karena itu beberapa persoalan yang terkait dengan penanaman-pemahaman tentang kaidah bahasa Arab yang tidak ada sama sekali dan nilai-nilai keagamaan yang kurang diaplikasikan, metode pembelajaran yang konvensional dan perbaikan sarana-prasarana yang menjadi kebutuhan yang sangat mendasar dan harus diutamakan dapat diselesaikan secara bersama-sama yakni dengan team bersama mitra dalam kegiatan tersebut.

\section{e. Potret Permasalahan Lain yang Terekam}

Permasalahan lainnya yang terekam dalam pengabdian adalahsebagai berikut:

1) Permasalahan SDM para guru yang ada di dusun murbaya Lombok tengah juga masih perlu mendapatkan perhatian, karena kebanyakan dari mereka hanya membaca kitab-kitab klasik, dan sangat diharapkan adanya tambahan refrensi terkait dengan sumber bacaan yang terbaru dan metode belajar mengajar.

2) Pemberian insentif mengajar kepada para guru ngaji yang tidak memiliki penghasilan tetap, karena menjadi buruh tani, atau guru honorer di sekolah swasta yang penghasilan mereka tidak menentu disamping untuk memenuhi kebutuhan hidup keluarga. Jika tidak ada insentif yang cukup berdampak pada SDM yang kurang memadai, dan waktu luang para ustaz yang tidak cukup untuk membina remaja, dengan demikian proses pendidikan keagamaan pembinaan akhlaq para remaja dan mendalami ilmu pendukung seperti mempelajari kaidah bahasa Arab (ilmu nahwu) akan jauh dari harapan karena terhambat masalah ekonomi dan SDM.

3) Terdapat sebagian dari para remaja yang motivasinya rendah untuk memperdalam ilmuilmu agama dan ilmu pendukung lainnya, karena beberapa faktor yaitu kurangnya perhatian orang tua, kurangnya kesadaran remaja akan dampak dari penggunaan media social yang tidak tepat guna dan banyaknya pengangguran selepas dari SMA sehingga mereka memilih untuk bekerja jadi TKI ke malaisia atau ke Kalimantan.

\section{F. TARGET Dan LUARAN YANG DICAPAI}

Dari program pengabdian ini, kami menargetkan bahwa dalam pengabdian yang telah terlaksana selama enam pekan, kami dari tim pengabdian kepada masyarakat memberikan perubahan yang signifikan diantaranya adalah:

a. Dari segi sarana dan prasana belajar yang kurang mendukung menjadi lebih baik.

b. Pengalaman belajar khususnya sumber pengambilan hukum dari kitab fiqih, hadis atau dari al-Qur'an dapat difahami secara lebih baik sehingga para remaja memiliki wawasan keagamaan yang lebih dari sebelumnya, begitu juga dengan pemahamannya terhadap tata bahasa Arab menjadi lebih baik dan meningkat.

c. Dan luaran dari pengabdian ini telah diterbitkan di jurnal Ibtidai'y Prodi pendidikan Guru Madrasah Ibtidaiyah fakultas Agama Islam Universitas Muhammadiyah Mataram. 


\section{G. SIMPULAN DAN SARAN}

\section{a. Simpulan}

Dalam seluruh kegian pengabdian masyarakat yang telah dilaksanakann dapat disimpulkan sebagai berikut:

1) Para remaja masjid Baitussalam Murbaya yang mengikuti bimbingan mendapatkan banyak pengetahuan mengenai metode pembelajaran , peserta didik bisa membaca kitab syarah AlJurumiyah dan mengetahui tata cara memahami dasar pengambilan hukum serta dalil yang benar sesuai dengan al-Qur'an dan Hadits Sohih.

2) Motivasi Remaja Masjid terlihat meningkat karena ada perbaikan dan tambahan sarana dan prasarana TPQ Al-Mustofa Murbaya.

3) Para remaja memiliki kesadaran akan pentingnya menambah wawasan keilmuan untuk memperkuat iman dan Islam yang akan berefek positif pada ketinggian akhlaq dan akan menciptakan generasi yang berjiwa besar dalam menghadapi tantangan zaman.

\section{b. Saran}

Dari hasil pengabdian yang berlangsung selama tujuh pekan pada remaja Masjid Baitussalam Murbaya. Lombok Tengah diharapkan lebih termotifasi untuk meningkatkan pemahaman dan pengamalan ilmu agama serta ilmu pendukungnya. adapun untuk pihak kampus agar tetap memberikan bimbingan yang berkelanjutan demi tercapainya masyarakat yang Islami.

\section{H. DAFTAR RUJUKAN}

1. Syarah Al-Jurumiyah

2. Kitab matan al-jurumiyah

3. Nahwu Al-Wadih 